\title{
ApoE mimetic peptide decreases $A \beta$ production in vitro and in vivo
}

\author{
S Sakura Minami', Antoinette Cordova², John R Cirrito5, Joseph A Tesoriero³, Lenard W Babus 3 , Gary C Davis², \\ Sivanesan Dakshanamurthy², R Scott Turner ${ }^{3}$, Daniel TS Pak4, G William Rebeck', Mikell Paige*2 and Hyang- \\ Sook Hoe*1,3
}

\begin{abstract}
Background: Apolipoprotein $E$ (apoE) is postulated to affect brain A levels through multiple mechanisms--by altering amyloid precursor protein (APP) processing, A $\beta$ degradation, and A $\beta$ clearance. We previously showed that an apoEderived peptide containing a double repeat of the receptor-binding region was similarly effective in increasing APP processing in vivo. Here, we further examined whether peptides containing tandem repeats of the apoE receptorbinding region (amino acids 141-149) affected APP trafficking, APP processing, and A $\beta$ production.

Results: We found that peptides containing a double or triple tandem repeat of the apoE receptor-binding region, LRKLRKRLL, increased cell surface APP and decreased A 3 levels in PS1-overexpressing PS70 cells and in primary neurons. This effect was potentiated by a sequential increase in the number of apoE receptor-binding domain repeats (trimer > dimer > monomer). We previously showed that the apoE dimer increased APP CTF in vivo; to determine whether the dimer also affected secreted APP or A levels, we performed a single hippocampal injection of the apoE dimer in wild-type mice and analyzed its effect on APP processing. We found increased sAPPa and decreased A levels at $24 \mathrm{hrs}$ after treatment, suggesting that the apoE dimer may increase a-secretase cleavage.

Conclusions: These data suggest that small peptides consisting of tandem repeats of the apoE receptor-binding region are sufficient to alter APP trafficking and processing. The potency of these peptides increased with increasing repeats of the receptor binding domain of apoE. In addition, in vivo administration of the apoE peptide (dimer) increased SAPPa and decreased A levels in wild-type mice. Overall, these findings contribute to our understanding of the effects of apoE on APP processing and $A \beta$ production both in vitro and in vivo.
\end{abstract}

\section{Background}

Alzheimer's disease (AD) is an age-related neurodegenerative disease characterized by the progressive loss of synapses and neurons and by the formation of amyloid plaques and neurofibrillary tangles [1]. Amyloid plaques are composed predominantly of the $A \beta$ peptide, a 40 or 42 amino acid cleavage product of the amyloid precursor protein (APP). APP is a synaptic, transmembrane protein that undergoes extracellular cleavage by one of two proteases, $\alpha$ - or $\beta$-secretase, which results in the formation of large $\mathrm{N}$-terminal extracellular fragments of

*Correspondence: map65@georgetown.edu, hh69@georgetown.edu

1 Department of Neuroscience, Georgetown University, 3970 Reservoir Rd. NW, Washington, DC 20057, USA

2 Drug Discovery and Drug Therapeutics, Georgetown University, 3970

Reservoir Rd. NW, Washington, DC 20057, USA

Full list of author information is available at the end of the article secreted APP (sAPP) and smaller, membrane-bound Cterminal fragments (CTF). If the initial cleavage event occurs via $\beta$-secretase, then cleavage of the CTF by $\gamma$ secretase in the intramembrane region results in the formation of A $\beta$. Mutations in APP and in a component of the $\gamma$-secretase complex (presenilin) cause familial forms of AD. APP can be preferentially cleaved by $\alpha$ - or $\beta$-secretase depending on its localization within the cell. The majority of $\alpha$-secretase activity is thought to occur on the cell surface [2], whereas $\beta$-secretase cleavage and $A \beta$ production is thought to occur following endocytosis of APP in the endosomal pathway [3]. Understanding APP function, trafficking, and processing in neurons may provide valuable information in generating interventions against $A D$ pathogenesis and its accompanying memory loss. 
ApoE is the major genetic risk factor for $\mathrm{AD}$ (reviewed in Roses, 2006 [4]) and is known to directly bind $A \beta$ and co-localize with cerebral amyloid deposits in AD patients [5-8]. However, the mechanism by which apoE and its receptors affect the risk for AD remains unknown. Some possible effects of apoE include altering APP processing [9], facilitating internalization and degradation of $A \beta[10-$ 13], improving clearance of $A \beta$ into the periphery [14], and altering neuronal toxicity of $\mathrm{A} \beta$ [15]. However, some studies show detrimental effects of apoE where apoE facilitates $A \beta$ oligomerization $[16,17]$. Some of the contrasting evidence may be attributed to the different isoforms of apoE: human apoE 2 reduces brain $A \beta$ burden in transgenic APP mice, while human apoE4 increases brain $A \beta$ burden [18]. These isoform specific effects were also seen in APP transgenic mice expressing human apoE, where A $\beta$ deposition was greatest in apoE4 APP transgenic mice compared to apoE3 and apoE2 $[19,20]$. Recombinant human apoE at physiological levels (100 $\mathrm{nM}$ ) has been reported to decrease $\mathrm{A} \beta$ production in CHO-APP751, HEK293, and primary neuron cells [21]. However, other studies show that lipid deficient apoE4 in APP-overexpressing rat neuroblastoma B103 cells increased $\mathrm{A} \beta$ production compared to lipid deficient apoE3 [22], and apoE binding to apoEr2 promoted APP endocytosis, increasing $A \beta$ production [23]. Thus, there is no consensus yet about how apoE affects APP processing.

We and others [24-26] have used a derivative of apoE, a small peptide containing a tandem repeat of the receptor binding domain, to show the effects of apoE on neuronal signaling and APP processing. We found that apoEderived peptide treatment increased ERK and decreased JNK activation in primary neurons [27]. In addition, the apoE-derived peptide significantly reduced inflammation in several animal models of disease [28,29], which may occur through the apoE peptide-induced decrease in c-Jun $\mathrm{N}$-terminal kinase-mediated microglial activation [30]. Furthermore, we chronically administered the apoEderived peptide via osmotic pump and observed a consistent effect on apoE signaling, as well as on APP processing, in vivo [25]. These data implicate a role for the apoEderived peptide, regardless of isoform, in various signaling processes in neurons and glia, and these signaling processes may be related to our observed effects on altered APP processing.

In the present study, we investigated the importance of the tandem repeat in the apoE-derived peptide, and the ability of this peptide to affect APP trafficking, APP processing, and $A \beta$ levels. We first demonstrate that a tandem repeat in the apoE-derived peptide is necessary to effect cell surface APP levels. We then show that apoEderived peptides decrease secreted A $\beta$ in PS1-overexpressed PS70 cells and in primary neurons. Again, the effect of the monomer was minimal in reducing secreted A $\beta$ levels in both systems, whereas the dimer and trimer show a clear dose response. The potency of the apoEderived peptides follows the order: trimer $>$ dimer $>$ monomer, which correlates with the stability of their alpha helical secondary structure as determined computationally. The effect of the dimer on APP processing was further evaluated in vivo, where a single hippocampal injection of the apoE-derived dimer peptide resulted in a significant increase in $\mathrm{SAPP} \alpha$ and a significant decrease in soluble $A \beta 1-40$ levels in wild-type mice, suggesting that the apoE dimer may promote $\alpha$-secretase cleavage. Our data demonstrate a clear effect of the apoE-derived dimer peptide on APP trafficking, processing, and A $\beta$ levels both in vitro and in vivo.

\section{Results}

\section{Characterization of apoE peptides}

ApoE-derived peptides have been found in several studies, including our own, to be involved in reducing inflammation and in increasing APP processing [25,26,30]. This peptide sequence was derived from the receptor-binding domain of apoE (LRKLRKRLL). In our previously published studies, we used an apoE-derived peptide that consisted of a tandem repeat of this sequence, labeled as the dimer in this study (Table 1). To test the importance of the tandem repeat of the apoE-derived mimetic peptide in affecting APP processing and A $\beta$ production, we also synthesized the single LRKLRKRLL sequence denoted as the monomer, and the triple tandem repeat, (LRKLRKRLL) 3 , denoted as the trimer (Table 1).

Based on the structure of the apoE receptor binding domain, we hypothesized that these peptides could exist as alpha helices with varying degrees of stability, which may result in differences in binding efficacy. Therefore, a computational study was employed to determine the relative stability of the three apoE-derived peptides as alpha helices. As shown in Table 2, the alpha helical structure of the trimer is considerably more stable than the dimer by approximately $2.4 \mathrm{kcal} / \mathrm{mol}$, and the alpha helical structure of the dimer is more stable than the monomer by approximately $2.0 \mathrm{kcal} / \mathrm{mol}$.

The propensity of the LRKLRKRLL motif to form alpha helices was further investigated by a search through the

Table 1: Amino acid sequences of the apoE-derived peptides used.

\begin{tabular}{ll}
\hline Peptide & Sequence \\
\hline Monomer & LRKLRKRLL \\
Dimer & LRKLRKRLLLRKLRKRLL \\
Trimer & LRKLRKRLLLRKLRKRLLLRKLR \\
& KRLL \\
\hline
\end{tabular}


Table 2: E values for monomer, dimer, and trimer apoEderived peptides.

\begin{tabular}{ll}
\hline Peptide & $\boldsymbol{E}(\mathbf{k c a l} / \mathbf{m o l})$ \\
& \\
\hline Monomer & 6.75 \\
Dimer & 8.77 \\
Trimer & 11.21 \\
\hline Energy change of each structure was computed by molecular \\
simulations as described.
\end{tabular}

Dihedral Angle and Secondary Structure Database of Short Amino Acid Fragments (DASSD). [REFERENCE: Dayalan S, Gooneratne ND, Bevinakoppa S, Schroder H: Dihedral angle and secondary structure database of short amino acid fragments Bioinformation 2006, 1:7880] The DASSD database stores the dihedral angles and the secondary structure details of short amino acid fragments derived from 5,227 non-redundant protein structures with less than $2 \AA$ resolution. A search of the LRK motif revealed that 222 out 311 structures (71\%) in the DASSD database contained the LRK motif in alpha helices according to STRIDE classification. Similarly, a search of the RLL motif revealed that 300 out of 476 structures (63\%) contained this sequence in an alpha helix. A representative sample of unique structures that contain these motifs in alpha helical structures are given by the following PDB codes: 1EWK, 1YKE, 2CWY, 1WUD, 1CII, 2GHI, 3KS9, 2QR4, and 1TTY. This supports our hypothesis that the LRK and RLL motifs in our apoEderived peptides have propensities toward forming alpha helical structures.

\section{ApoE dimer is not toxic to PS70 cells or primary neurons}

In order to first test the potential toxicity of our compounds, we treated PS70 cells (a PS1-overexpressing cell line which produces high levels of $A \beta$ ) with PBS control or increasing doses of the apoE-derived peptide dimer ( $30 \mathrm{nM}, 300 \mathrm{nM}, 1 \mathrm{uM}, 3 \mathrm{uM}$ ) for $24 \mathrm{~h}$ and conducted an MTT assay to evaluate for cell viability. We found that there was no toxicity of the peptide compared to control at any concentration tested (Fig. 1A). We also tested for toxicity of this compound in primary neuronal cells. Again, we did not observe any toxicity at any of the concentrations tested compared to control (Fig. 1B).

\section{ApoE dimer and trimer promote surface levels of APP in COS7 cells}

Trafficking of APP to the cell surface may be important for effects on APP processing, as specific secretases are known to be distinctly localized within the cell. $\beta$ - and $\gamma$ secretases are predominantly present intracellularly in endosomes, and $\alpha$-secretase is active at the cell surface

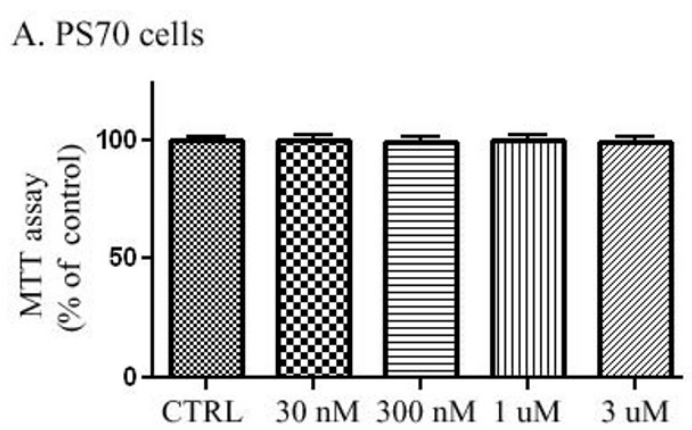

B. Primary neurons

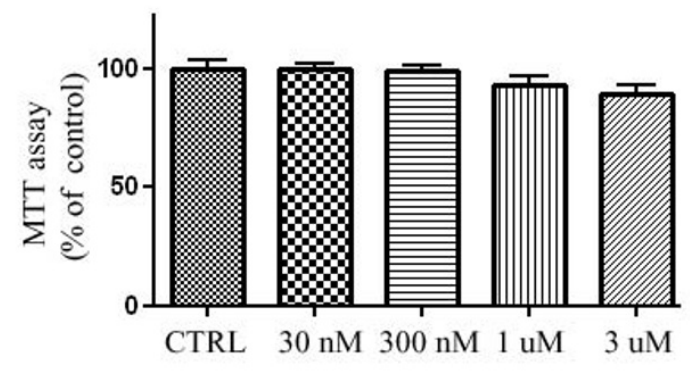

Figure 1 ApoE-derived peptide does not affect cell viability in PS70 or primary neuronal cells. A. PS70 cells overexpressing PS1 were treated with apoE dimer at various concentrations for $24 \mathrm{~h}$ and cell viability was assayed $(n=6)$. ApoE dimer treatment did not result in cell toxicity at any of the indicated concentrations. B. Primary neurons were treated with apoE dimer at various concentrations for $24 \mathrm{~h}$ and cell viability was assayed $(n=6)$. ApoE dimer treatment did not result in cell toxicity at any of the indicated concentrations.

$[31,32]$. To examine the effects of apoE peptides on cell surface levels of APP, we transfected COS7 cells with APP and treated cells with control, $1 \mu \mathrm{M}$ monomer, $1 \mu \mathrm{M}$ dimer, or $1 \mu \mathrm{M}$ trimer for $24 \mathrm{~h}$. Cell surface proteins were biotin labeled, isolated with avidin beads, and immunoblotted for APP. Monomer treatment caused a non-significant $12 \%$ increase in cell surface levels of APP (Fig. 2A \&2B). The dimer and the trimer treatments significantly increased cell surface levels of APP by $98 \%$ and 197\%, respectively (Fig. $2 \mathrm{C}$-F). Levels of cell $\beta$-actin were consistent across conditions, serving as a loading control (Fig. $2 \mathrm{~A}-\mathrm{C}$, bottom panels). These data suggest that the tandem repeat of the receptor-binding region of apoE is necessary for our apoE-derived peptides to affect APP trafficking.

\section{ApoE-derived peptides increase cell surface APP in primary cortical and hippocampal neurons}

To test whether the apoE mimetic peptides regulate endogenous APP trafficking in primary cortical neuronal cells, we treated cells with control (PBS) or $1 \mu \mathrm{M}$ apoE monomer for $24 \mathrm{hrs}$. Cell surface proteins were biotinylated, isolated with avidin beads, and immunoblotted for 
A

B
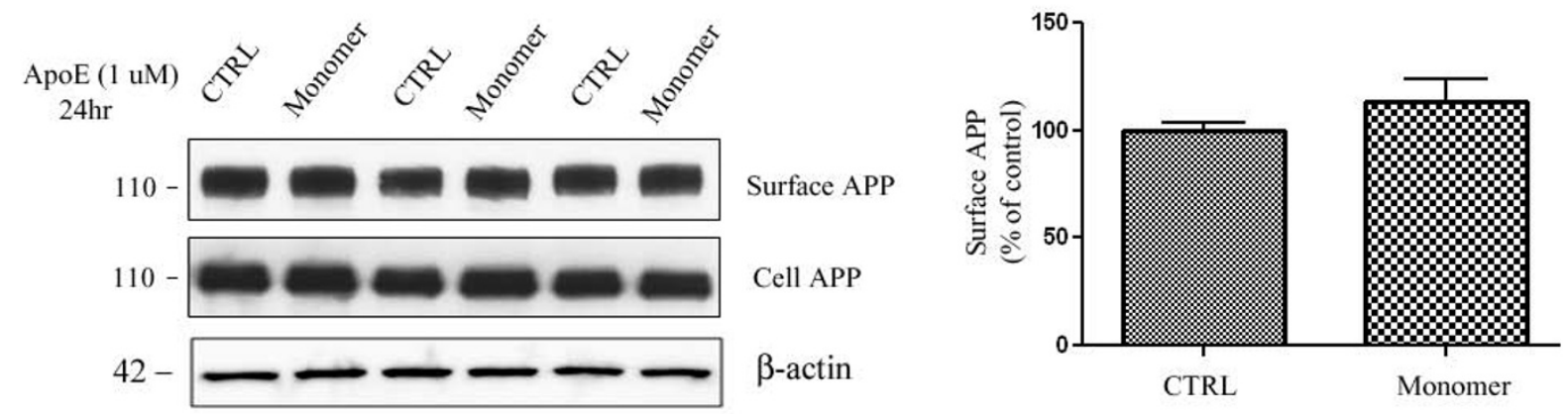

C

D

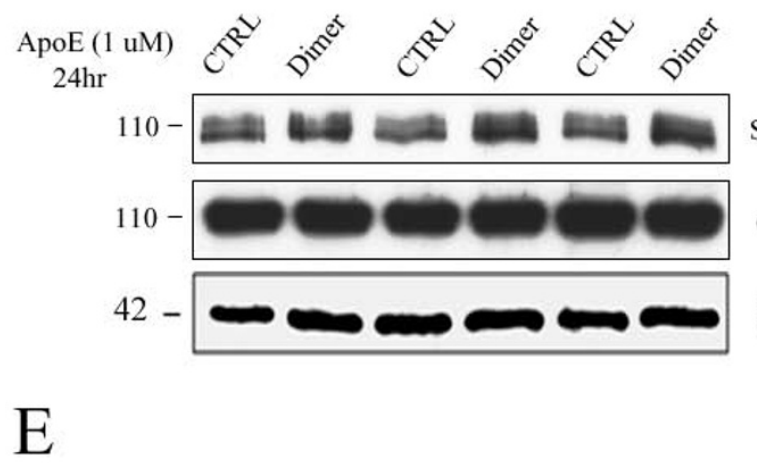

Surface APP

Cell APP

$\beta$-actin
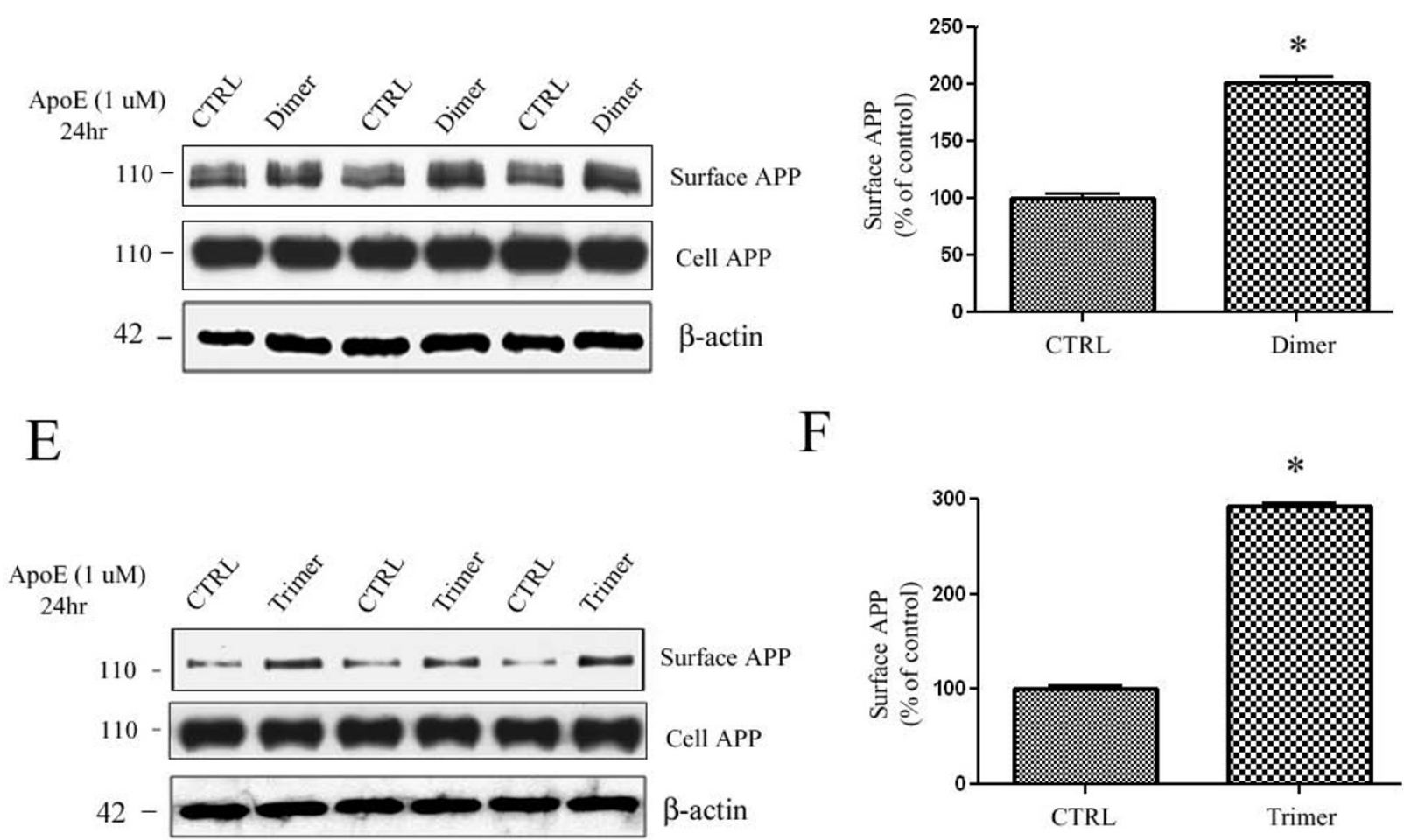

Figure 2 ApoE-derived peptide regulates APP trafficking in COS7 cells. COS7 cells were transiently transfected with APP and treated with control or apoE monomer $(n=3, \mathbf{A})$, apoE dimer $(n=3, \mathbf{C})$, or apoE trimer $(n=3, \mathbf{E})$ for $24 \mathrm{~h}$. Total APP and $\beta$-actin levels in cell lysates were measured for loading control (lower panels). Quantification of biotin-labeled cell surface APP in COS7 cells showed a 12\% (B), 98\% (D), and 197\% (F) increase in surface APP by the apoE monomer (NS: no significant), dimer, and trimer, respectively $\left(n=3,{ }^{*} p<0.01\right)$. Levels of $\beta$-actin in the cell lysate were consistent across conditions (bottom panels).

APP with antibody 22C11. ApoE monomer did not alter cell surface levels of APP (Fig. 3A-B).

We also examined the effect of apoE dimer and trimer on surface APP levels in cultured cortical neurons by treating with $1 \mu \mathrm{M}$ apoE dimer or trimer for $24 \mathrm{hrs}$ and found increased surface levels of endogenous APP after
24 hrs of apoE dimer (by $72 \%, \mathrm{n}=3, \mathrm{p}<0.01$ ) and trimer (by $166 \%, n=3, p<0.001$ ) treatment (Fig. 3C-D). These results are consistent with those obtained in COS7 cells (Fig. 2), where we observed an effect of apoE dimer and trimer, but not monomer, on increased cell surface APP levels. 
A

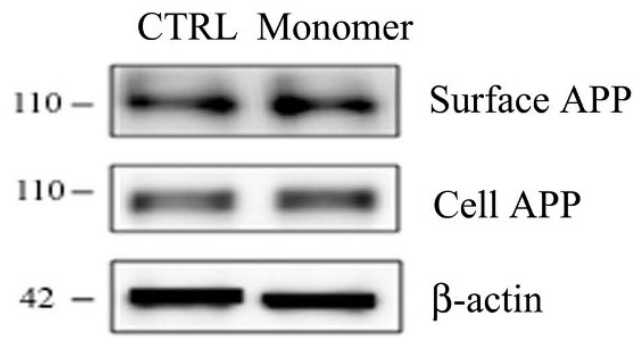

$\mathrm{C}$

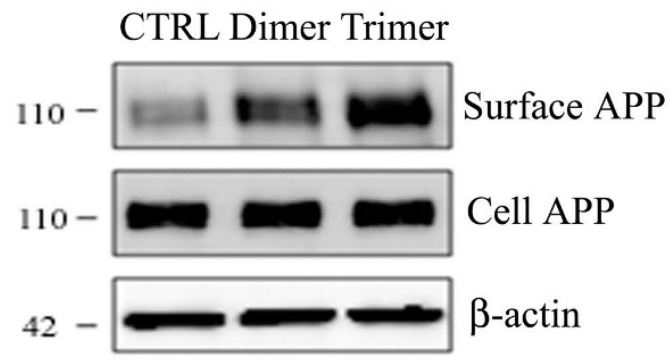

$\mathrm{E}$

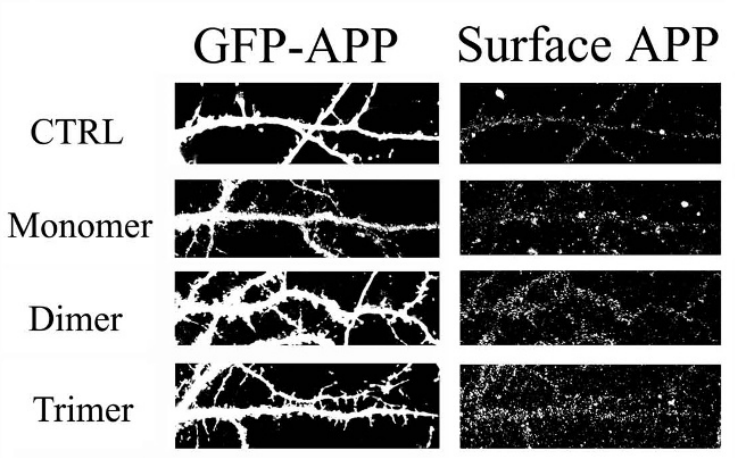

B

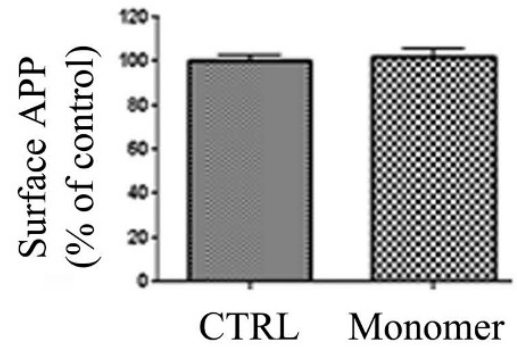

D

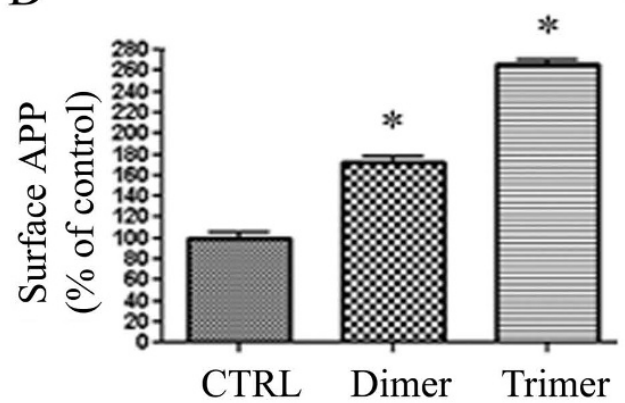

F

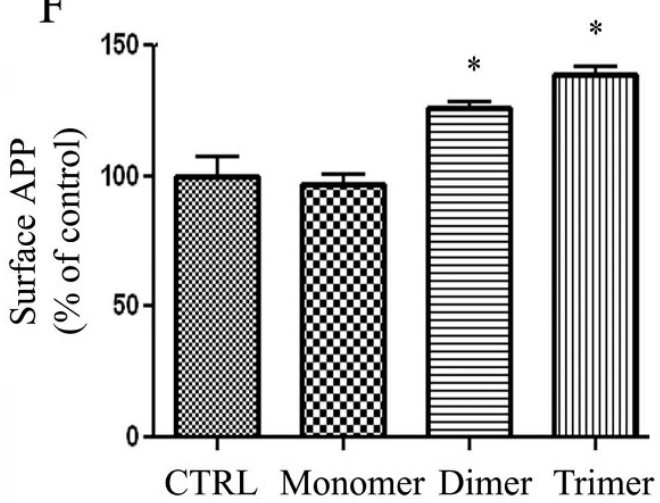

Figure 3 ApoE-derived peptide affects APP trafficking in primary cortical and hippocampal neuronal cells. A. Cultured cortical neuronal cells were treated with control (PBS) or apoE monomer ( $n=3,1 \mu \mathrm{M}$ for $24 \mathrm{hr}$ ). Cell surface proteins were biotinylated, isolated with avidin-conjugated beads, and immunoblotted with 22C11 antibody against rodent APP. Total APP and $\beta$-actin in cell lysates were measured in the bottom panel. B. Quantification of biotin-labeled cell surface APP in primary cortical neurons showed no significant change by apoE monomer compared to control. C. Cultured cortical neuronal cells were treated with control (PBS), apoE dimer, or apoE trimer ( $n=3,1 \mu \mathrm{M}$ for $24 \mathrm{hr}$ ). Total APP and $\beta$-actin in cell lysates were measured in the bottom panel. D. Quantification of biotin-labeled cell surface APP showed a $72 \%(p<0.01, n=3)$ and $166 \%(p<0.001, n=3)$ increase in surface APP by the apoE dimer and trimer, respectively. Error bars indicate SEM. E. Cultured hippocampal neurons were transfected at DIV12 with GFP conjugated APP. At DIV 14 cells were treated with PBS control or the apoE monomer $(n=10,1 \mu M)$, dimer $(n=10,1 \mu M)$, or trimer $(n$ $=10,1 \mu \mathrm{M}$ ) for $24 \mathrm{~h}$, and surface APP was measured by live cell staining. F. Quantification of surface APP intensity in (A) showed a $21 \%$ and $43 \%$ increase by the dimer and trimer, respectively $\left(n=10,{ }^{*} p<0.05,{ }^{*} p<0.01\right)$.

To further test whether the apoE mimetic peptides regulate APP trafficking in primary hippocampal neurons, we transfected hippocampal neurons with $\mathrm{N}$-terminal GFP-tagged APP and treated cells with control or $1 \mu \mathrm{M}$ of the apoE monomer, dimer, or trimer for $24 \mathrm{~h}$. Transfection of cells with APP allowed us to measure surface APP by live cell immunostaining. The dimer and trimer treatments significantly increased cell surface levels of APP (Fig. 3E, third and fourth panels). Quantification of these data showed significant $21 \%$ and $43 \%$ increases in surface APP by the dimer and trimer in primary hippocampal neuronal cells, respectively $\left(\mathrm{n}=10,{ }^{*} \mathrm{p}<0.05,{ }^{*} \mathrm{p}<0.01\right.$, 
Fig. 3F). These data are consistent with our cell surface biotinylation results, and support a role for apoE dimer and trimer peptides in altering APP trafficking.

\section{ApoE-derived peptides significantly decrease $A \beta$ levels in PS70 cells}

The above data suggest that the apoE mimetics may decrease $\beta$-cleavage of APP by changing APP trafficking to favor $\alpha$-cleavage. To directly test whether the apoEderived peptide analogs could affect $\mathrm{A} \beta$ production, we treated a human PS1-overexpressing cell line (PS70) with the apoE mimetic peptides at various concentrations (30 $\mathrm{nM}$ to $3 \mu \mathrm{M}$ ) for $24 \mathrm{~h}$ and measured $\mathrm{A} \beta 1-40$ levels from the conditioned media by ELISA. We found that treatment with the apoE monomer resulted in small but significant decreases in A $\beta 1-40$ compared to control (20\% decreases at $30 \mathrm{nM}$ and $100 \mathrm{nM}(\mathrm{p}<0.05) ; 30 \%$ decreases at $300 \mathrm{nM}, 1 \mu \mathrm{M}$, and $3 \mu \mathrm{M}(\mathrm{p}<0.01)(\mathrm{n}=7$ for all concentrations except $3 \mu \mathrm{M}, \mathrm{n}=5$ ) (Fig. 4A)). The dimer and trimer resulted in larger significant dose-dependent decreases in A $\beta 1-40$ (dimer: $35 \%$ decrease at $30 \mathrm{nM}(\mathrm{p}<$ $0.01) ; 51 \%$ decrease at $100 \mathrm{nM} ; 64 \%$ decrease at $300 \mathrm{nM}$; $77 \%$ decrease at $1 \mu \mathrm{M} ; 90 \%$ decrease at $3 \mu \mathrm{M}$ (each $\mathrm{p}<$ $0.001)$; trimer: $68 \%$ decrease at $100 \mathrm{nM} ; 72 \%$ decrease at $500 \mathrm{nM} ; 85 \%$ decrease at $1 \mu \mathrm{M}$ (each $\mathrm{p}<0.001)(\mathrm{n}=6$ for all dimer concentrations and for the control trimer; $n=4$ for all concentrations of the trimer) (Fig. 4B-C)). Again, we observed a consistent effect where the monomer was least effective and the trimer was most effective in reducing $A \beta 1-40$ levels. These data suggest that increasing the number of tandem repeats of the receptor binding domain increases the potency of the apoE mimetic peptides in lowering $\mathrm{A} \beta$. We performed a control experiment to demonstrate that the apoE peptide did not interfere with the ELISA assay, and found that measurement of human A $\beta 1-40$ was not different in the presence of PBS or apoE dimer peptide (Fig. 4D).

\section{ApoE-derived peptides significantly decrease $A \beta$ levels in primary neuronal cells}

In order to determine whether the apoE peptide could affect $A \beta$ production in a more relevant system, we treated primary neuronal cells (DIV 14) with various concentrations of the apoE peptides (monomer, dimer, or trimer) and measured rodent A $\beta 1-40$ by ELISA after $24 \mathrm{~h}$. Treatment with the apoE monomer did not result in significant decreases in $\mathrm{A} \beta 1-40$ (Fig. $5 \mathrm{~A})(\mathrm{n}=5)$, but treatment with the apoE dimer and trimer resulted in significant dose-dependent decreases in A $\beta 1-40$ (dimer: $19 \%$ decrease at $500 \mathrm{nM}(\mathrm{p}<0.05) ; 27 \%$ decrease at $1 \mu \mathrm{M}$ $(\mathrm{p}<0.01)(\mathrm{n}=5)$ (Fig. 5B); trimer: $12 \%$ decrease at 100 $\mathrm{nM}(\mathrm{p}<0.05) ; 18 \%$ decrease at $500 \mathrm{nM}(\mathrm{p}<0.05) ; 28 \%$ decrease at $1 \mu \mathrm{M}(\mathrm{p}<0.001)(\mathrm{n}=5)($ Fig. 5C)). As with our previous experiment, we performed a control experiment to demonstrate that the apoE peptide did not interfere with the ELISA assay, and found that measurement of rodent $A \beta 1-40$ was not different in the presence of PBS or apoE dimer peptide (Fig. 5D).

\section{ApoE-derived peptide increases secreted APPa and decreases $A \beta$ production in vivo}

We have thus far demonstrated that the apoE dimer regulates APP trafficking and A $\beta$ production in vitro; to test whether the dimer affected endogenous APP proteolysis in vivo, we injected PBS control or a $10 \mathrm{mM}$ solution of the dimer (in a $2 \mu \mathrm{L}$ volume) into the hippocampus of wild-type mice. After $4 \mathrm{~h}$ or $24 \mathrm{~h}$, we dissected the tissue surrounding the injection site from each brain and measured endogenous rodent $\mathrm{sAPP} \alpha$ and $\mathrm{sAPP} \beta$ by western blot. We found that SAPP $\alpha$ was not altered at $4 \mathrm{~h}$, but was significantly increased by $77 \%$ at 24 h by the dimer com-

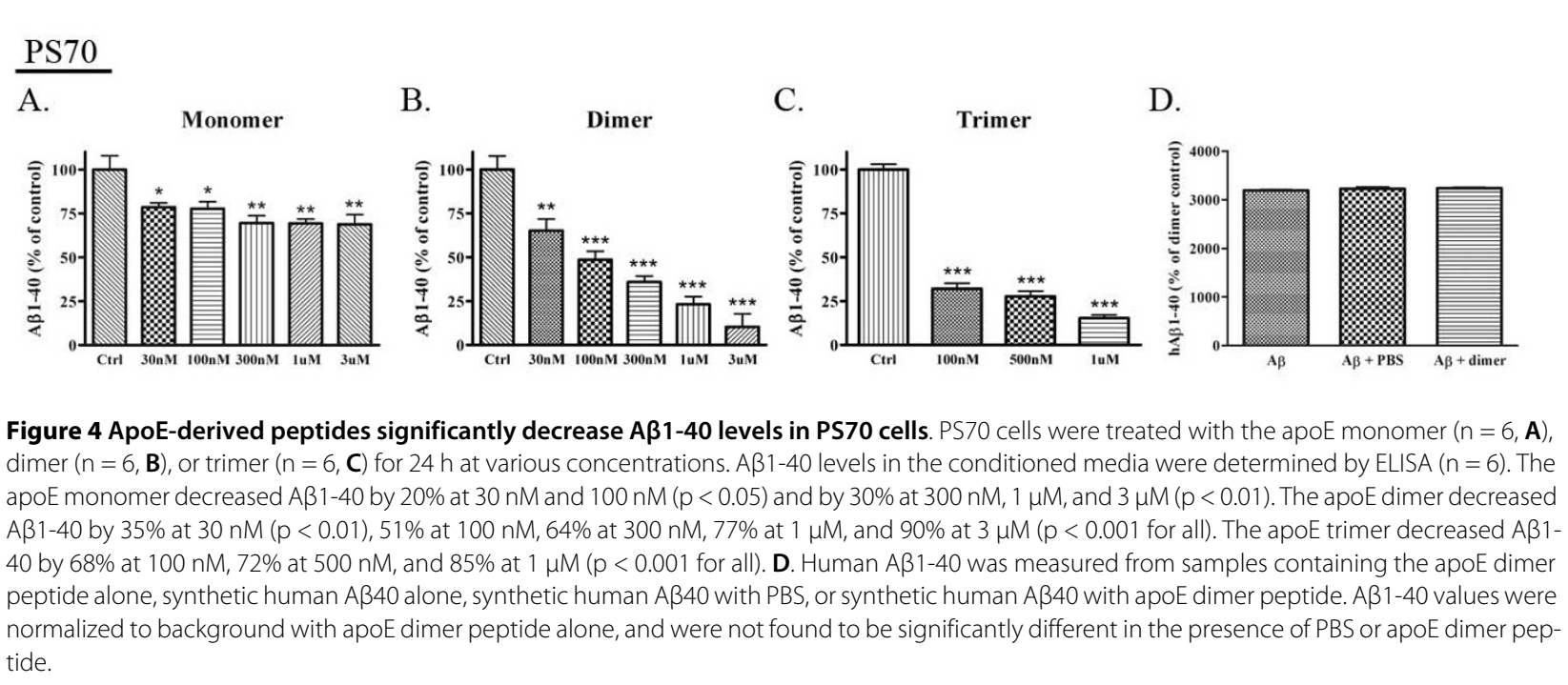




\section{Primary neurons}

A.

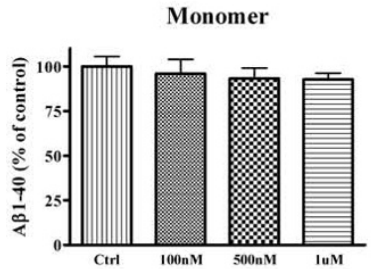

B.

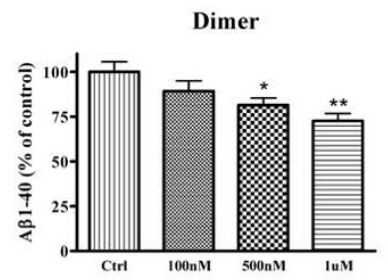

C.

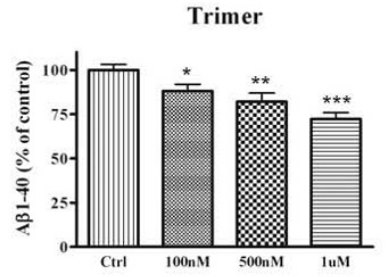

D.

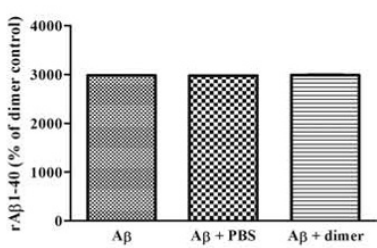

Figure 5 ApoE-derived peptides significantly decrease $A \beta 1-40$ levels in primary cortical neuronal cells. Primary cortical neurons were treated with apoE monomer $(n=6, \mathbf{A})$, dimer $(n=6, \mathbf{B})$, or trimer $(n=6, \mathbf{C})$ for $24 h$, and A 1 1-40 levels in the conditioned media were determined by ELISA ( $n$ =6). Treatment of primary neurons with apoE dimer decreased $A \beta 1-40$ by $19 \%$ at $500 \mathrm{nM}(p<0.05)$ and $27 \%$ at $1 \mu \mathrm{M}(\mathrm{p}<0.01)$. Treatment with apoE trimer decreased $A \beta 1-40$ by $12 \%$ at $100 \mathrm{nM}(p<0.05), 18 \%$ at $500 \mathrm{nM}(p<0.05)$, and $28 \%$ at $1 \mu \mathrm{M}(p<0.001)$. D. Rodent $A \beta 1-40$ was measured from samples containing the apoE dimer peptide alone, synthetic rodent $A \beta 40$ alone, synthetic rodent $A \beta 40$ with PBS, or synthetic rodent $A \beta 40$ with apoE dimer peptide. A 1-40 values were normalized to background with apoE dimer peptide alone, and were not found to be significantly different in the presence of PBS or apoE dimer peptide.

pared to controls (Fig. 6A \&6B, upper panel, $n=6$ ). We did not find significant differences in $\mathrm{SAPP} \beta$ compared to controls (Fig. 6A \&6C, second panel, $n=6$ ). $\beta$-actin loading controls were consistent across samples (Fig. 6A, bottom panel).

We did not observe a significant difference in A $\beta 40$ levels in mice treated with $10 \mathrm{mM}$ apoE dimer at $4 \mathrm{hrs}$ or 24 hrs (data not shown). To test whether a lower, more physiologically relevant, concentration of the dimer affected endogenous $\mathrm{A} \beta$ production in vivo, we injected $1 \mathrm{mM}$ or $10 \mathrm{mM}$ solutions of the dimer (in a $2 \mu \mathrm{L}$ volume) into the hippocampus of wild-type mice. We analyzed endogenous rodent $A \beta 1-40$ by ELISA (Fig. $6 \mathrm{D}$ ). We found that A $\beta 1-40$ was significantly decreased by $40 \%$ with the 1 $\mathrm{mM}$ apoE dimer injection after $24 \mathrm{~h}$ treatment $(\mathrm{n}=9)$ compared to controls (PBS, $n=9$ ) (Fig. 6D). We found a similar, but not statistically significant, decrease in $A \beta 1$ 40 with the $10 \mathrm{mM}$ apoE dimer injection after $24 \mathrm{~h}(\mathrm{n}=$ 8 ). We also tested whether endogenous rodent $A \beta 1-42$ levels were altered with treatment. We did not observe any significant difference in $A \beta 1-42$ levels following apoE peptide treatment at $1 \mathrm{mM}$ or $10 \mathrm{mM}$ (Fig. 6E). To test whether the dimer interfered with rodent $A \beta 1-42$ ELISA detection, we assayed for rodent $A \beta 1-42$ in the presence of PBS or apoE dimer peptide and found no significant difference compared to A $\beta 1-42$ alone (Fig. 6F). These data suggest that a single $1 \mathrm{mM}$ injection of apoE dimer lowers endogenous $A \beta 1-40$ production in vivo.

\section{Discussion}

In these studies, we tested whether single (monomer), double (dimer), or triple (trimer) repeats of the receptorbinding domain of apoE had an effect on $A \beta$ levels in vitro and in vivo and whether this effect was accompanied by changes in APP trafficking or processing. We showed that the apoE dimer and trimer increased cell surface
APP levels in vitro (Fig. 2 \&3). We also observed a dosedependent decrease in secreted A $\beta$ levels from PS70 cells and primary neurons treated with either dimer or trimer (Fig. 4 \&5). Finally, we found an in vivo effect of apoE dimer treatment, where we observed increased sAPP $\alpha$ and decreased $A \beta$ at 24 hours following a single hippocampal injection of the apoE dimer (Fig. 6). These data support the idea that the apoE receptor-binding domain, especially in either double or triple tandem repeat form, significantly increases cell surface APP and secretion of sAPP $\alpha$, and decreases A $\beta$ levels.

Previous studies have implicated a role for apoE, and the apoE mimetic peptide, in modulating APP processing by increasing APP CTFs both in vitro and in vivo $[21,25]$. We hypothesized that regulation of APP trafficking could mediate this effect, and found that the apoE dimer and trimer increased cell surface levels of APP in vitro (Fig. 2 \&3). This increase in cell surface APP could lead to reduced availability of APP to cleavage by $\beta$ - and $\gamma$ secretases, which are predominantly present in early endosomes and may promote $\alpha$-secretase cleavage, resulting in the previously observed increase in APP CTFs and decrease in $A \beta$ production.

Full-length apoE has been shown to decrease secreted $\mathrm{A} \beta$ levels in vitro [21], and here, we show that the apoE monomer, dimer, and trimer were sufficient to lower $A \beta$ levels in human PS1-overexpressing PS70 cells (Fig. 4). Although the apoE monomer efficiently reduced $A \beta$ levels, it was much less effective than the apoE dimer or trimer. The apoE dimer and trimer induced a significant dose-dependent decrease in $\mathrm{A} \beta$, and the apoE trimer further reduced secreted $A \beta$ levels compared to the apoE dimer. We observed a similar, albeit less dramatic, decrease in rodent $A \beta$ from primary hippocampal neurons (Fig. 5). This decrease was most apparent in response to the apoE trimer, less so in response to the 


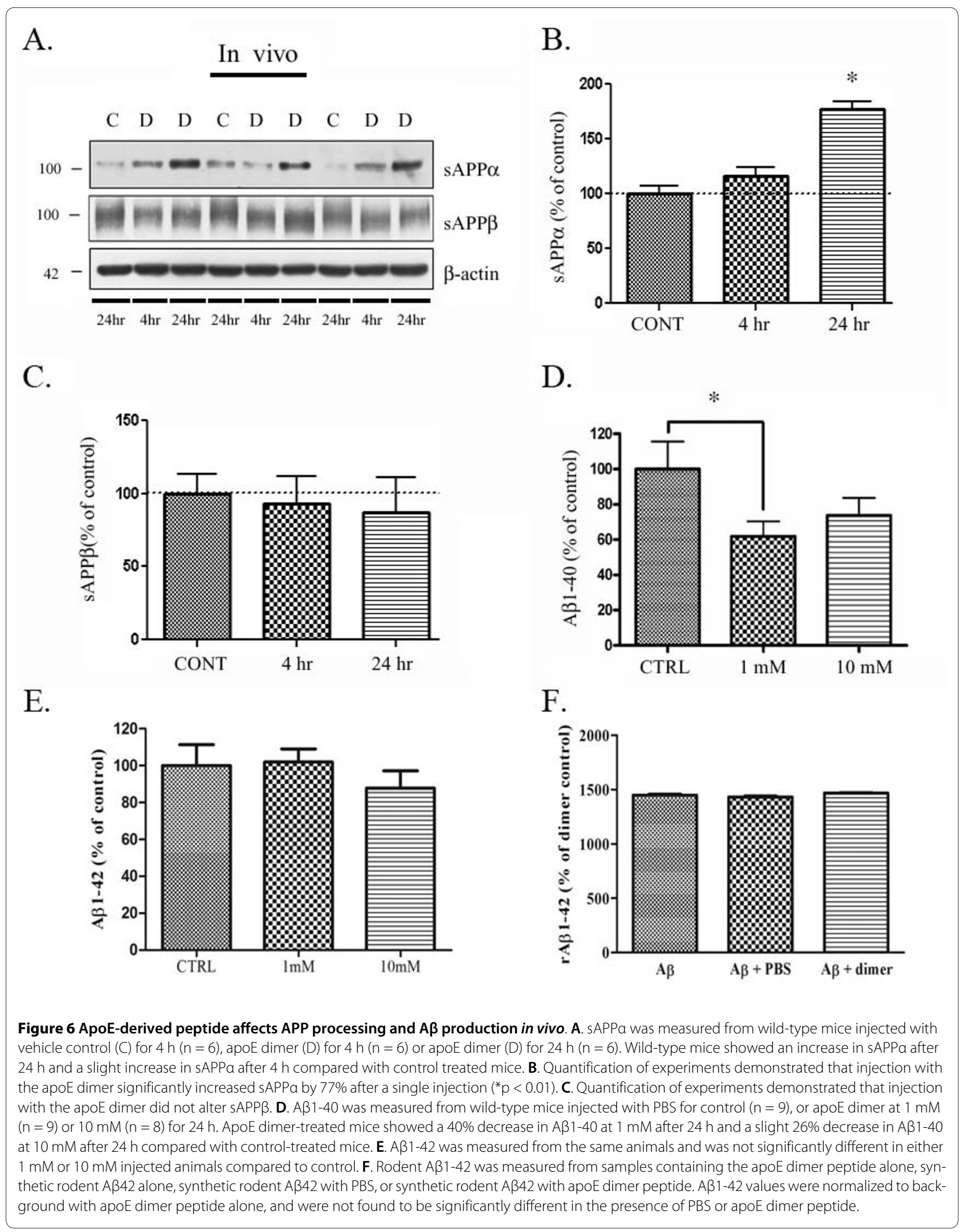


apoE dimer, and not significant in response to the apoE monomer. We hypothesize that we were able to observe a much greater effect in PS70 cells due to the abundant levels of APP and A $\beta$ in this system. Our investigation of endogenous $A \beta$ production in primary neurons demonstrates an important effect of apoE peptide on $A \beta$ production in the absence of overexpression. In addition, the data from both PS70 cells and primary neurons are consistent in supporting the idea that additional repeats of the receptor-binding domain significantly increase the effect of the apoE-derived peptides on lowering secreted A $\beta$ levels, as well as on increasing APP trafficking.

Thus, we hypothesize that increasing the number of residues confers greater stability of the alpha helical structure, which results in a more rigid conformation and consequently reduced overall energy for binding. Computational analyses revealed that the stability of the alpha helix of the apoE-derived peptides are on the order of trimer $>$ dimer $>$ monomer, where the trimer is $2.4 \mathrm{kcal} /$ mol more stable than the dimer and the dimer is $2.0 \mathrm{kcal} /$ mol more stable than the monomer. Further structural analyses including NMR spectroscopy, x-ray crystallography, and circular dichroism spectroscopy should be employed in future studies to determine the threedimensional structure of these peptides and test the hypothesis that increasing the number of receptor binding domain repeats increases the alpha helical nature of the peptide. Alternatively, we hypothesize that multiple receptor-binding domains may increase the ability of the peptide to bind multiple ligands, thus increasing its effect on APP trafficking and processing. However, these possibilities are not mutually exclusive, as increased stability of the alpha helix may contribute to the peptide binding multiple ligands.

Importantly, when we tested whether the apoE-derived peptide affected APP processing and A $\beta$ levels in vivo, we found that 24 hours of treatment with the apoE dimer resulted in a significant increase in sAPP $\alpha$ levels (Fig. 6A). sAPP $\beta$ levels were unchanged (Fig. 6C); however, we observed a significant decrease in soluble $A \beta 1-40$, but not A $\beta 1-42$, levels following treatment with the apoE dimer (Fig. 6D). We hypothesize that we were not able to detect significant differences in A $\beta 1-42$ due to the low levels of endogenous $A \beta 1-42$ produced in the wild-type mouse. It will be interesting for future studies to determine whether apoE peptides can alter A $\beta 1-42$ in APP overexpressing mice. It is important to note that at least two mechanisms contribute to the total measured levels of soluble $A \beta$--one involving APP processing and $A \beta$ production, and the other involving $A \beta$ degradation and clearance $[12,14]$. Here, we show that the apoE-derived peptide dimer affects $\alpha$-secretase cleavage of APP as well as $\mathrm{A} \beta$ levels in vivo. However, the observed decrease in $\mathrm{A} \beta$ could be due to either or both apoE-mediated altera- tions in APP processing and A $\beta$ clearance. Full-length apoE has been shown to effectively internalize and degrade $A \beta$ through neurons and microglia $[11,33]$. Thus, our data suggest that the major mechanism underlying apoE-mediated $A \beta$ lowering may involve alterations to APP trafficking and $\alpha$-secretase processing.

\section{Conclusions}

In summary, we provide data supporting a role for an apoE mimetic peptide in increasing trafficking of APP to the cell surface, increasing $\alpha$-secretase cleavage of APP, and decreasing $A \beta$ levels in vitro and in vivo, which is facilitated by the presence of multiple receptor-binding tandem repeats. These data implicate new roles for apoE in APP trafficking as well as in APP processing, and provide further evidence that apoE, regardless of isoform, decreases $A \beta$ levels in wild-type mice. In addition, the present study provides new insight regarding the structure-based action of apoE on APP trafficking and processing and $\mathrm{A} \beta$ production.

\section{Methods \\ Chemicals}

The apoE-derived peptides consist of the monomer (LRKLRKRLL), the dimer (LRKLRKRLLLRKLRKRLL), and the trimer (LRKLRKRLLLRKLRKRLLLRKLRKRLL). The monomer represents the receptor-binding region of apoE (amino acids 141 through 149), and the dimer and trimer represent double and triple tandem repeats of the monomer, respectively. The peptides were synthesized by standard solid phase peptide synthesis (SPPS) with acetylation of the N-terminus and amidation at the C-terminus. Synthesis of the peptides was contracted through Biomatik USA, LCC (Wilmington, DE). The dimer peptide has signaling properties comparable to full-length apoE (Tolar et al., 1999), and does not contain amino acids that differ between apoE isoforms. We used antibody 6E10 (Signet) for detecting cell surface APP and C1/6.1 (from Dr. Paul Matthews) for total APP in biotinylation experiments. We used an APP N-terminal antibody (Sigma) to detect surface APP in live cell surface staining experiments. Antibody clone 2B3 (IBL, Gunma, Japan) was used to detect sAPP $\alpha$, a rabbit polyclonal SAPP $\beta$ antibody was used to detect wild-type sAPP $\beta$ (IBL), and monoclonal $\beta$-actin antibody (sigma) was used to confirm loading control.

\section{Computation Methods}

The monomer, dimer and trimer structural models were based primarily on the $\mathrm{x}$-ray structure of apoE (PDB:1GS9). The E values indicate the energy change of each structure after energy minimization. The apoE monomer, dimer and trimer were energy minimized using consistent valence force field (CFF91) with the 
default partial atomic charges available in Discover, Insight II (Accelrys Inc.). The cutoff for nonbonded interaction energies was set to $\infty$ (no cutoff). To avoid unrealistic movements of the peptide caused by computational artifacts, the structures were relaxed gradually. Each minimization was conducted in two steps, first using steepest descent minimization for 200 cycles and then using conjugate gradient minimization until the average gradient fell below $0.01 \mathrm{kcal} / \mathrm{mol}$.

\section{Cell Lines and Culture Conditions}

COS7 (monkey kidney) cells or PS70 (Chinese hamster ovarian $(\mathrm{CHO})$ cells overexpressing wild-type human PS1 and producing high levels of $A \beta$ [34]) cells were used for our experiments. Cells were maintained in Opti-MEM (Invitrogen) with $10 \%$ fetal bovine serum (Invitrogen) in a $5 \% \mathrm{CO}_{2}$ incubator. COS7 cells were transiently transfected with 0.5-1 $\mu \mathrm{g}$ of plasmid in FuGENE 6 (Roche Applied Science) according to the manufacturer's protocol and cultured $24 \mathrm{~h}$ in Dulbecco's modified Eagle's medium containing $10 \%$ fetal bovine serum. After $24 \mathrm{~h}$ the cells were transferred to Opti-MEM serum-free media (Invitrogen) and treated with indicated apoE peptides. Cells were collected $24 \mathrm{~h}$ later for subsequent analyses.

\section{MTT Assay}

MTT assay was performed in either PS70 cells or primary cortical neurons. $1 \mathrm{mg} / \mathrm{ml}$ MTT solution was prepared in PBS and $50 \mu \mathrm{l}$ of this solution and $200 \mu \mathrm{l}$ of DMEM without phenol red were added into each well. Cells were incubated for 4 hours at $37^{\circ} \mathrm{C}$ with $5 \% \mathrm{CO}_{2}$. After 4 hours, the MTT solution was removed and replaced with $200 \mu \mathrm{l}$ DMSO and $25 \mu \mathrm{l}$ Sorenson's glycine buffer (glycine $0.1 \mathrm{M}$, $\mathrm{NaCl} 0.1 \mathrm{M}, \mathrm{pH}: 10.5)$. The plate was further incubated for $5 \mathrm{~min}$ at room temperature, and the optical density (OD) was determined using a plate reader at a test wavelength of $570 \mathrm{~nm}$ and a reference wavelength of $630 \mathrm{~nm}$.

\section{Cell surface biotinylation}

COS7 cells were cultured $24 \mathrm{~h}$ in Opti-MEM containing $10 \%$ fetal bovine serum, then transferred to Opti-MEM serum-free media and treated with indicated apoE peptides. After $24 \mathrm{~h}$, cells were washed twice with phosphatebuffered saline, and surface proteins were labeled with Sulfo-NHS-SS-Biotin, $500 \mu \mathrm{l}$ at $500 \mu \mathrm{g} / \mathrm{ml}$ phosphatebuffered saline (Pierce) under gentle shaking at $4^{\circ} \mathrm{C}$ for 30 min. $50 \mu \mathrm{l}$ of quenching solution (Pierce) was added to cells at $4^{\circ} \mathrm{C}$, which were washed twice with Tris-buffered saline. Cells were lysed in $500 \mu \mathrm{l}$ of lysis buffer, collected with a cell scraper, disrupted by sonication on ice, incubated for $30 \mathrm{~min}$ on ice, and clarified by centrifugation $(10,000 \times g, 2 \mathrm{~min})$. To isolate biotin-labeled proteins, lysate was added to immobilized NeutroAvidin TM Gel
$(50 \mu \mathrm{l})$ and incubated for $1 \mathrm{~h}$ at room temperature. Gels were washed 5 times with wash buffer and incubated for $1 \mathrm{~h}$ with SDS-PAGE sample buffer including $50 \mathrm{~mm}$ dithiothreitol. Surface proteins were then analyzed by immunoblotting.

Primary Neuronal Culture and Cell Surface Immunostaining Primary hippocampal or cortical neurons from E18-19 Sprague-Dawley rats were cultured at 150 cells $/ \mathrm{mm}^{2}$ as described (17). Neurons were transfected with GFP conjugated APP at 10-12 days in vitro by calcium phosphate precipitation (4-5 $\mu \mathrm{g}$ of DNA/well). 2 days after transfection, cells were treated with apoE peptides for $24 \mathrm{~h}$, and cell surface expression levels of APP were analyzed. Surface immunostaining was performed as described previously (18). Briefly, live neuron cultures were incubated with anti-APP $\mathrm{N}$ terminal antibody $(10 \mu \mathrm{g} / \mathrm{ml}$ in conditioned medium) for $10 \mathrm{~min}$ to specifically label surface APP, then lightly fixed for $5 \mathrm{~min}$ in 4\% paraformaldehyde (non-permeabilizing conditions). After fixation, the surface-remaining antibody labeled APP was measured with Alexa Fluor 555-linked $\alpha$-rabbit secondary antibodies for $1 \mathrm{~h}$. Images were collected using a Zeiss LSM510 confocal microscope (Carl Zeiss, Thornwood, NY). Confocal zseries image stacks encompassing entire neurons were analyzed using Metamorph software (Universal Imaging Corp., Downingtown, PA) (18).

\section{In vivo analysis of APP fragments}

Mouse brains were homogenized in a $10 \times$ volume of 50 $\mathrm{mM}$ Tris- $\mathrm{HCl}$ buffer, $\mathrm{pH}$ 7.6, containing $250 \mathrm{mM}$ sucrose and protease inhibitor cocktail (Sigma, St. Louis, MO). Soluble APP and A $\beta$ were extracted in $0.4 \%$ DEA, as previously described (Nishitomi et al., 2006) Briefly, crude $10 \%$ brain homogenate was mixed with an equal volume of $0.4 \%$ DEA, sonicated, and ultracentrifuged for 1 hour at $100,000 \times \mathrm{g}$. The supernatant was collected and neutralized with $10 \% 0.5 \mathrm{M}$ Tris base, $\mathrm{pH}$ 6.8. The resulting DEA fraction was used for Western blot and ELISA analyses.

\section{A $\beta$ ELISAs}

Levels of endogenous full-length mouse $A \beta 1-40$ from the media from primary neurons or wild-type brain DEA fractions were quantified using sandwich ELISA as previously described (Nishitomi et al., 2006). Briefly, a 96-well plate (Maxisorp) was coated with an anti-A $\beta 40$ antibody, clone $1 \mathrm{~A} 10$, overnight at $4^{\circ} \mathrm{C}$. After blocking for $2 \mathrm{hrs}$, standards (synthetic mouse $\mathrm{A} \beta$ peptide 1-40) and samples were loaded and incubated overnight at $4^{\circ} \mathrm{C}$. The plate was incubated with HRP-coupled detection antibody, $14 \mathrm{~F} 1$, and visualized using a 3,3',5,5'-tetra methyl benzidine (TMB) substrate. Rodent A $\beta 1-42$ levels were mea- 
sured from wild-type brain DEA fractions by an ELISA kit purchased from Invitrogen (Carlsbad, CA).

Human A $\beta 1-40$ levels were measured from the media of PS70 cells using sandwich ELISA as previously described (Horikoshi et al., 2004), using anti-A 440 antibody clone $1 \mathrm{~A} 10$ as the capture antibody and antibody clone $82 \mathrm{E} 1$ as the detection antibody.

\section{Surgical procedures}

For single brain injections, mice were anesthetized with ketamine/xylazine (Sigma) and placed in a stereotaxic apparatus (David Kopf Instruments, Tujunga, CA, USA). $2 \mu \mathrm{L}$ vehicle (PBS) or $2 \mu \mathrm{L} 10 \mathrm{mM}$ apoE dimer peptide in $\mathrm{PBS}$ was injected into the dorsal hippocampus (AP $=-1.0$ $\mathrm{mm}, \mathrm{ML}=+1.8 \mathrm{~mm}, \mathrm{DV}=-2.2 \mathrm{~mm}$ ) from the bregma according to Paxinos and Watson (1998). Solutions were continuously delivered over a duration of 4 minutes. After completion of each injection, the cannula was left in place for an additional $4 \mathrm{~min}$ in order to accomplish quantitative diffusion of the volume delivered. At the appropriate survival times, animals were sacrificed, and the hippocampus and surrounding cortex were dissected and collected.

\section{Statistical analysis}

Experiments were repeated a minimum of three times unless otherwise noted. All data were analyzed using ANOVA with Graphpad Prism 5 software, using Tukey's multiple comparison test for post hoc analyses with significance determined as $p<0.05$. Descriptive statistics are displayed as mean \pm SEM.

\section{Competing interests}

The authors declare that they have no competing interests.

\section{Authors' contributions}

$A C, S D$, and MP performed structural analyses on the chemical compounds; SSM, JRC, HSH, JAT, LWB, and GCD conducted experiments. SSM, MP, and HSH prepared the manuscript, GWR, RST, and DTSP provided resources and valuable scientific insight, and MP and HSH supervised the overall project. All authors have read and approved the final manuscript.

\section{Acknowledgements}

This work is supported by NIH AG 032330 (HSH), NIH AG 032330-02S1 (HSH), NIH AG 034253 (HSH), NIH AG 026478 (RST) and NIH AG014473 (GWR). JAT and LWB were supported by a grant to Georgetown University from the Undergraduate Program at the Howard Hughes Medical Institute. We thank Dr. Paul Matthews (Nathan Kline Institute, New York, NY) for the C1/6.1 antibody.

\footnotetext{
Author Details

'Department of Neuroscience, Georgetown University, 3970 Reservoir Rd. NW, Washington, DC 20057, USA, 2Drug Discovery and Drug Therapeutics, Georgetown University, 3970 Reservoir Rd. NW, Washington, DC 20057, USA, 3Department of Neurology, Georgetown University, 4000 Reservoir Rd. NW, Washington, DC 20057, USA, 4Department of Pharmacology, Georgetown University Medical Center, 3900 Reservoir Rd. NW, Washington, DC 20057, USA and ${ }^{5}$ Department of Neurology, Washington University, St. Louis, MO 63110 , USA
}

Received: 16 February 2010 Accepted: 20 April 2010

Published: 20 April 2010

\section{References}

1. Saura CA, Choi SY, Beglopoulos V, Malkani S, Zhang D, Shankaranarayana Rao BS, Chattarji S, Kelleher RJ, Kandel ER, Duff K, et al.: Loss of presenilin function causes impairments of memory and synaptic plasticity followed by age-dependent neurodegeneration. Neuron 2004, 42:23-36.

2. Lammich S, Kojro E, Postina R, Gilbert S, Pfeiffer R, Jasionowski M, Haass C, Fahrenholz F: Constitutive and regulated alpha-secretase cleavage of Alzheimer's amyloid precursor protein by a disintegrin metalloprotease. Proc Natl Acad Sci USA 1999, 96:3922-3927.

3. Huse JT, Pijak DS, Leslie GJ, Lee VM, Doms RW: Maturation and endosomal targeting of beta-site amyloid precursor protein-cleaving enzyme. The Alzheimer's disease beta-secretase. J Biol Chem 2000, 275:33729-33737

4. Roses AD: On the discovery of the genetic association of Apolipoprotein E genotypes and common late-onset Alzheimer disease. J Alzheimers Dis 2006, 9:361-366.

5. Namba Y, Tomonaga M, Kawasaki H, Otomo E, Ikeda K: Apolipoprotein E immunoreactivity in cerebral amyloid deposits and neurofibrillary tangles in Alzheimer's disease and kuru plaque amyloid in CreutzfeldtJakob disease. Brain Res 1991, 541:163-166.

6. Naslund J, Thyberg J, Tjernberg LO, Wernstedt C, Karlstrom AR, Bogdanovic N, Gandy SE, Lannfelt L, Terenius L, Nordstedt C Characterization of stable complexes involving apolipoprotein $\mathrm{E}$ and the amyloid beta peptide in Alzheimer's disease brain. Neuron 1995, 15:219-228.

7. LaDu MJ, Lukens JR, Reardon CA, Getz GS: Association of human, rat, and rabbit apolipoprotein E with beta-amyloid. J Neurosci Res 1997, 49:9-18.

8. Tokuda T, Calero M, Matsubara E, Vidal R, Kumar A, Permanne B, Zlokovic B, Smith JD, Ladu MJ, Rostagno A, et al.: Lipidation of apolipoprotein E influences its isoform-specific interaction with Alzheimer's amyloid beta peptides. Biochem J 2000, 348(Pt 2):359-365.

9. Dodart JC, Bales KR, Johnstone EM, Little SP, Paul SM: Apolipoprotein E alters the processing of the beta-amyloid precursor protein in APP(V717F) transgenic mice. Brain Res 2002, 955:191-199.

10. Zerbinatti CV, Wahrle SE, Kim H, Cam JA, Bales K, Paul SM, Holtzman DM, $\mathrm{Bu}$ G: Apolipoprotein $\mathrm{E}$ and low density lipoprotein receptor-related protein facilitate intraneuronal Abeta42 accumulation in amyloid model mice. J Biol Chem 2006, 281:36180-36186.

11. Beffert U, Aumont N, Dea D, Lussier-Cacan S, Davignon J, Poirier J: Betaamyloid peptides increase the binding and internalization of apolipoprotein E to hippocampal neurons. J Neurochem 1998 70:1458-1466

12. Jiang Q, Lee CY, Mandrekar S, Wilkinson B, Cramer P, Zelcer N, Mann K, Lamb B, Willson TM, Collins JL, et al:: ApoE promotes the proteolytic degradation of Abeta. Neuron 2008, 58:681-693.

13. Koistinaho M, Lin S, Wu X, Esterman M, Koger D, Hanson J, Higgs R, Liu F, Malkani S, Bales KR, Paul SM: Apolipoprotein E promotes astrocyte colocalization and degradation of deposited amyloid-beta peptides. Nat Med 2004, 10:719-726.

14. Zlokovic BV: New therapeutic targets in the neurovascular pathway in Alzheimer's disease. Neurotherapeutics 2008, 5:409-414.

15. Moulder KL, Narita M, Chang LK, Bu G, Johnson EM Jr: Analysis of a novel mechanism of neuronal toxicity produced by an apolipoprotein Ederived peptide. J Neurochem 1999, 72:1069-1080.

16. Sanan DA, Weisgraber KH, Russell SJ, Mahley RW, Huang D, Saunders A, Schmechel D, Wisniewski T, Frangione B, Roses AD, et al:: Apolipoprotein $E$ associates with beta amyloid peptide of Alzheimer's disease to form novel monofibrils. Isoform apoE4 associates more efficiently than apoE3. J Clin Invest 1994, 94:860-869.

17. Strittmatter WJ, Weisgraber KH, Huang DY, Dong LM, Salvesen GS, PericakVance M, Schmechel D, Saunders AM, Goldgaber D, Roses AD: Binding of human apolipoprotein $\mathrm{E}$ to synthetic amyloid beta peptide: isoformspecific effects and implications for late-onset Alzheimer disease. Proc Natl Acad Sci USA 1993, 90:8098-8102.

18. Dodart JC, Marr RA, Koistinaho M, Gregersen BM, Malkani S, Verma IM, Paul SM: Gene delivery of human apolipoprotein E alters brain Abeta burden in a mouse model of Alzheimer's disease. Proc Natl Acad Sci USA 2005, 102:1211-1216.

19. Fagan AM, Watson M, Parsadanian M, Bales KR, Paul SM, Holtzman DM: Human and murine ApoE markedly alters A beta metabolism before 
and after plaque formation in a mouse model of Alzheimer's disease. Neurobiol Dis 2002, 9:305-318.

20. Holtzman DM, Bales KR, Tenkova T, Fagan AM, Parsadanian M, Sartorius LJ, Mackey B, Olney J, McKeel D, Wozniak D, Paul SM: Apolipoprotein E isoform-dependent amyloid deposition and neuritic degeneration in a mouse model of Alzheimer's disease. Proc Natl Acad Sci USA 2000, 97:2892-2897.

21. Irizarry MC, Deng A, Lleo A, Berezovska O, Von Arnim CA, MartinRehrmann M, Manelli A, LaDu MJ, Hyman BT, Rebeck GW: Apolipoprotein E modulates gamma-secretase cleavage of the amyloid precursor protein. J Neurochem 2004, 90:1132-1143.

22. Ye S, Huang Y, Mullendorff K, Dong L, Giedt G, Meng EC, Cohen FE, Kuntz ID, Weisgraber KH, Mahley RW: Apolipoprotein (apo) E4 enhances amyloid beta peptide production in cultured neuronal cells: apoE structure as a potential therapeutic target. Proc Natl Acad Sci USA 2005, 102:18700-18705.

23. He X, Cooley K, Chung CH, Dashti N, Tang J: Apolipoprotein receptor 2 and X11 alpha/beta mediate apolipoprotein E-induced endocytosis of amyloid-beta precursor protein and beta-secretase, leading to amyloid-beta production. J Neurosci 2007, 27:4052-4060.

24. Hoe HS, Rebeck GW: Regulation of ApoE receptor proteolysis by ligand binding. Brain Res Mol Brain Res 2005, 137:31-39.

25. Hoe HS, Pocivavsek A, Dai H, Chakraborty G, Harris DC, Rebeck GW: Effects of apoE on neuronal signaling and APP processing in rodent brain. Brain Res 2006, 1112:70-79.

26. Laskowitz DT, McKenna SE, Song P, Wang H, Durham L, Yeung N, Christensen D, Vitek MP: COG a novel apolipoprotein E-based peptide, improves functional recovery in a murine model of traumatic brain injury. J Neurotrauma 2007, 24:1093-1107.

27. Hoe HS, Harris DC, Rebeck GW: Multiple pathways of apolipoprotein E signaling in primary neurons. J Neurochem 2005, 93:145-155.

28. Lynch JR, Wang H, Mace B, Leinenweber S, Warner DS, Bennett ER, Vitek MP, McKenna S, Laskowitz DT: A novel therapeutic derived from apolipoprotein $\mathrm{E}$ reduces brain inflammation and improves outcome after closed head injury. Exp Neurol 2005, 192:109-116.

29. Li FQ, Sempowski GD, McKenna SE, Laskowitz DT, Colton CA, Vitek MP: Apolipoprotein E-derived peptides ameliorate clinical disability and inflammatory infiltrates into the spinal cord in a murine model of multiple sclerosis. J Pharmacol Exp Ther 2006, 318:956-965.

30. Pocivavsek A, Burns MP, Rebeck GW: Low-density lipoprotein receptors regulate microglial inflammation through c-Jun $\mathrm{N}$-terminal kinase. Glia 2009, 57:444-453.

31. Hoe HS, Cooper MJ, Burns MP, Lewis PA, Brug M van der, Chakraborty G, Cartagena CM, Pak DT, Cookson MR, Rebeck GW: The metalloprotease inhibitor TIMP-3 regulates amyloid precursor protein and apolipoprotein E receptor proteolysis. J Neurosci 2007, 27:10895-10905.

32. Parvathy S, Hussain I, Karran EH, Turner AJ, Hooper NM: Cleavage of Alzheimer's amyloid precursor protein by alpha-secretase occurs at the surface of neuronal cells. Biochemistry 1999, 38:9728-9734

33. Cole GM, Ard MD: Influence of lipoproteins on microglial degradation of Alzheimer's amyloid beta-protein. Microsc Res Tech 2000, 50:316-324.

34. Xia W, Zhang J, Kholodenko D, Citron M, Podlisny MB, Teplow DB, Haass C, Seubert P, Koo EH, Selkoe DJ: Enhanced production and oligomerization of the 42-residue amyloid beta-protein by Chinese hamster ovary cells stably expressing mutant presenilins. $J$ Biol Chem 1997, 272:7977-7982.

doi: $10.1186 / 1750-1326-5-16$

Cite this article as: Minami et al., ApoE mimetic peptide decreases A? production in vitro and in vivo Molecular Neurodegeneration 2010, 5:16

\section{Submit your next manuscript to BioMed Central and take full advantage of:}

- Convenient online submission

- Thorough peer review

- No space constraints or color figure charges

- Immediate publication on acceptance

- Inclusion in PubMed, CAS, Scopus and Google Scholar

- Research which is freely available for redistribution

Submit your manuscript at www.biomedcentral.com/submit
C BioMed Central 